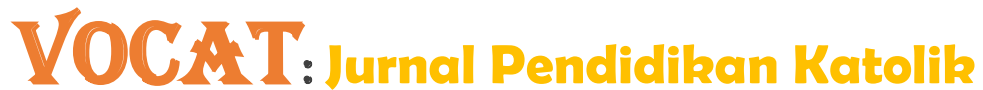

Website: https://ejournal.stakatnpontianak.ac.id/index.php/vocat

Volume 1, No. 1 Tahun 2021,

Halaman 1-7

\section{Implementasi Bimbingan dan Konseling dalam Meningkatkan Motivasi Belajar Siswa Kelas XI di Sekolah Menengah Kejuruan Santa Monika Kabupaten Kubu Raya}

\author{
Florentina \\ Sekolah Tinggi Agama Katolik Negeri Pontianak, Email : Flotina999@gmail.com
}

\section{Riwayat Artikel \\ Dikirim : 10 Oktober 2020 \\ Direvisi : 23 Oktober 2020 \\ Diterima : 4 November 2020}

\section{Abstrak}

Tujuan penelitian ini untuk menjawab: bagaimana pelaksanaan bimbingan dan konseling di Kelas XI Sekolah Menengah Kejuruan Santa Monika Kabupaten Kubu Raya? Bagaimana faktor pendukung dan penghambat dalam upaya memberikan motivasi belajar siswa di Kelas XI di Sekolah Menengah Kejuruan Santa Monika Kabupaten Kubu Raya? Bagaimana upaya yang dilakukan guru Bimbingan dan Konseling di dalam memberikan motivasi belajar siswa di Kelas XI di Sekolah Menengah Kejuruan Santa Monika Kabupaten Kubu Raya? Hasil penelitian menunjukkan bahwa implementasi bimbingan dan konseling dalam meningkatkan motivasi siswa kelas XI di SMK Santa Monika dilaksanakan dalam layanan orientasi, layanan informasi, layanan penempatan penyaluran, layanan penguasaan konten, layanan konseling perseorangan, layanan bimbingan kelompok, layanan konseling kelompok, layanan konsultasi, layanan mediasi, dan layanan advokasi. Program layanan bimbingan dan konseling masih belum maksimal. Faktor pendukung dari pelaksanaan bimbingan dan konseling pihak sekolah dan guru-guru pendukung dengan membuat program-program layanan bimbingan dan konseling. Faktor penghambat ialah kekurangan tenaga guru atau konselor, keterbatasan waktu, dan guru yang mengajar tidak terbiasa dalam mengajar di kelas. Upaya yang dilakukan oleh guru bimbingan dan konseling dalam meningkatkan motivasi belajar ialah mendata anak dengan pengisian identitas siswa, mengalami atau mendekati siswa, membuat program individu atau kelompok dan memberikan saran-saran terhadap siswa kelas XI di SMK Santa Monika Kabupaten Kubu Raya.

Kata kunci: Bimbingan dan Konseling, Motivasi Belajar Siswa

\begin{abstract}
Abtract
The purpose of this study is to answer: how is the implementation of guidance and counseling in Class XI Santa Monika Vocational High School, Kubu Raya Regency? What are the supporting and inhibiting factors in an effort to motivate students to learn in Class XI at Santa Monika Vocational High School, Kubu Raya Regency? How are the efforts made by the Guidance and Counseling teacher in providing student motivation in Class XI at the Santa Monika Vocational High School, Kubu Raya Regency? The results showed that the implementation of guidance and counseling in increasing the motivation of class XI students at SMK Santa Monika was carried out in orientation services, information services, distribution placement services, content mastery services, individual counseling services, group guidance services, group counseling services, consulting services, mediation, and advocacy services. The guidance and counseling service program is still not optimal. Supporting factors from the implementation of guidance and counseling by the school and supporting teachers by making guidance and counseling service programs. Inhibiting factors are the shortage of teachers or counselors, limited time, and teachers who teach are not used to teaching in class. Efforts made by guidance and counseling teachers in increasing learning motivation are recording children by filling in student identities, experiencing or approaching students, making individual or group programs and providing suggestions to class XI students at SMK Santa Monika, Kubu Raya Regency.
\end{abstract}

Key words: Guidance and Counseling, Student Motivation

\section{PENDAHULUAN}

Menuntut ilmu pengetahuan dengan belajar terusmenerus merupakan kewajiban bagi setiap orang, baik laki-laki maupun perempuan. Belajar boleh di manapun, kapanpun selama hayat masih dikandung badan. Tanpa belajar, seseorang akan tertinggal oleh cepatnya arus perubahan zaman dan kemajuan teknologi. Dalam menghadapi cepatnya perubahan zaman, manusia harus menyiapkan dirinya dengan Ilmu Pengetahuan dan Teknologi (IPTEK) serta membentengi diri dari dampak negatif yang ditimbulkan oleh kemajuan IPTEK dengan iman dan 
takwa. Oleh karena itu, seseorang harus membekali diri dengan pengetahuan umum dan pengetahuan agama yaitu dengan belajar.

Pemahaman tentang tugas perkembangan anak mutlak dimiliki oleh setiap orang yang berkecimpung dalam dunia pendidikan dan khususnya bimbingan dan konseling. Dalam tugas perkembangan anak tersebut terdapat perilaku-perilaku alamiah dan ciri-ciri yang memang secara naluriah muncul dalam setiap fasenya. Semisalnya anak yang masuk dalam fase remaja, mereka cenderung lebih dekat pada teman sebaya daripada orang tua atau guru. Mereka cenderung menghindari peran otoritatif dari orang yang lebih dewasa. Keinginan untuk menjadi populer di lingkungan sosial dan teman sebayanya, lebih dominan daripada kemauan mereka untuk metaati otoritas atau aturan sosial. Hal ini harus disadari secara penuh oleh para pendidik, karena menentukan perlakuan yang tepat dalam mendidik siswanya.

Program-program Bimbingan dan Konseling yang menjadi kebiasaan dan rutinitas selama ini yang hanya menyentuh kulit tanpa substansi. Misalnya mengadakan tes psikologi untuk siswa, namun hanya menjadi data base dan tidak dimanfaatkan untuk melakukan konseling menyeluruh yang pada dasarnya, secara ideal sangat membantu siswa dalam melakukan kegiatan akademiknya. Tes-tes yang hanya menjadi rutinitas tanpa bisa dimanfaatkan menjadi dasar pemetaan kondisi komprehensif siswa dalam hal akademis dan non akademis.

Implementasi Bimbingan dan Konseling menjadi krusial di saat faktor-faktor di luar kemampuan akademis, transfer pengetahuan dan proses belajarmengajar bukan menjadi faktor penghambat proses dan hasil belajar siswa. Faktor psikologis dan sosial siswa seringkali justru menjadi faktor yang dominan yang menghambat kemampuan siswa dalam memaksimalkan potensi akademisnya. Hal ini haruslah menjadi perhatian yang lebih bagi para praktisi bimbingan dan konseling serta pendidikan agar bisa membuat program kegiatan yang lebih komprehensif. Penanganan akademis dan non akademis (psikologis dan sosiologis) terhadap para siswa harus juga maksimal dilakukan, agar tidak mengganggu siswa dalam membangun dan mempertahankan potensi akademisnya ke arah yang lebih baik.

Peran Bimbingan dan Konseling dalam meningkatkan mutu pendidikan, tidak hanya terbatas pada bimbingan yang bersifat akademik tetapi juga sosial, pribadi intelektetual dan pemberian nilai. Bantuan bimbingan dan koseling maka pendidikan yang tercipta tidak hanya menciptakan manusia-

Florentina manusia yang berorientasi akademik tinggi, namun dalam kepribadian dan hubungan sosialnya rendah serta tidak mempunyai system nilai yang mengontrol dirinya sehingga yang dihasilkan pendidikan hanyalah robot-robot intelektual, dan bukannya manusia seutuhnya. Adanya bimbingan dan konseling maka integrasi dari seluruh potensi ini dapat dimunculkan sehingga keseluruhan aspek yang muncul, bukan hanya kognitif atau akademis saja tetapi juga seluruh komponen dirinya baik itu kepribadian, hubungan sosial serta memiliki nilai-nilai yang dapat dijadikan pegangan.

Jadi, dari sini dapat menyimpulkan bahwa peran Bimbingan dan Koseling di dalam meningkatkan mutu pendidikan terletak pada bagaimana bisa membangun manusia yang seutuhnya dari berbagai aspek yang ada di dalamnya peserta didik. Pendidikan yang bermutu bukanlah pendidikan yang hanya mentraformasikan ilmu pengetahuan dan teknologi saja tetapi juga harus meningkatkan profesionalitas dan sistem manajemen, dimana ke semuanya itu tidak hanya menyangkut aspek akademik tetapi juga aspek pribadi, sosial, kematangan intelektual, dan sistem nilai. Peran bimbingan dan konseling dalam keempat aspek inilah yang menjadikan bimbingan dan konseling ikut berperan dalam peningkatan mutu pendidikan. (Wardati dan Mohammad Jauhar, 2011:53-54).

Berbeda dengan siswa yang mendapatkan label positif, baik dan pintar. Justru biasanya mereka seringkali merasa gagal dalam memenuhi tugas perkembangannya, karena popularitas yang mereka dapatkan tidaklah sekuat yang mendapatkan label negatif, nakal dan kurang pintar. Mereka cenderung menjadi pendiam. Nampak tidak terlalu pintar bergaul, lingkungan pertemanan yang sempit dan tertutup pada lingkungannya. Hal ini menjadi berbahaya ketika justru kondisi tersebut menjadikan perhatian terhadap mereka berkurang dan tidak terpantau dengan baik. Mereka dianggap baik-baik saja dan berhasil, padahal justru ada kemungkinan besar bahwa mereka gagal dalam memenuhi tugas perkembangannya dan mungkin menyimpan permasalahan yang lebih kompleks daripada yang lain.

Jadi, sudah sepantasnyalah peran sekolah, khususnya Bimbingan dan Konseling untuk lebih menyadari serta memahami tentang tugas perkembangan anak, agar betul-betul bisa memuat program kegiatan yang lebih komprehensif dan menyentuh segala aspek dalam diri siswa, baik akademis maupun psikologis. Proses belajar-mengajar yang ditempuh dan dijalani oleh para siswa, betul-betul berdampak pada cara berpikir, pemaknaan dan Implementasi Bimbingan dan Konseling dalam Meningkatkan Motivasi .... 
aktualisasi diri dalam kehidupan mereka. Proses pendidikan menjadi lebih substantif dan bermakna karena secara ideal, kemampuan akademis dan psikologis harus betul-betul dimiliki oleh siswa sebagai bekal mereka menjalani kehidupan nyata di masyarakat. Substansi pendidikan nasional bisa lebih terimplementasi dengan baik.

Bimbingan dan konseling merupakan bagian integral dari sekolah yang bertujuan "memberikan bantuan kepada siswa baik perorangan maupun kelompok agar menjadi yang mandiri dan berkembang secara optimal, apalagi berkaitan dengan lembaga pendidikan yang secara khusus menjurus atau memilih skill tertentu seperti di Sekolah Menengah Kejuruan dan sekolah lainnya.

Latar belakang tersebut kiranya penulis tertarik untuk mengetahui lebih dekat tentang upaya-upaya yang dilakukan oleh guru Bimbingan dan Konseling dalam memberikan motivasi belajar siswa guna untuk mewujudkan cita-cita luhur pedoman pendidikan nasional Indonesia.

Dalam mengatasi masalah tersebut, tentunya pihak-pihak sekolah tidak tinggal diam, untuk mencapai tujuan pendidikan sekaligus untuk membentuk kepribadian siswa yang baik. Pihak Sekolah Menengah Kejuruan Santa Monika mengambil alternatif dengan lebih menekankan pendidikan baik melalui kegiatan intra kurikuler maupun ekstra kurikuler untuk menanamkan nilai-nilai agama dan mengoptimalkan pelayanan bimbingan dan konseling serta adanya kerja sama yang baik antara guru dan siswa.

Program ini bertujuan untuk meningkatkan motivasi belajar siswa, karena kompleksitas permasalahan yang terjadi pada siswa, sehinga dapat menurunkan motivasi belajar pada siswa.

\section{HASIL DAN PEMBAHASAN}

Bimbingan dan Konseling sudah dilaksanakan di SMK Santa Monika. Terbukti dengan pihak sekolah telah mengadakan Mata Pelajaran Bimbingan dan Konseling serta telah dilaksanakan. Dari hasil wawancara dengan Kepala Sekolah SMK Santa Monika JJ, pihak sekolah telah membuat programprogram Bimbingan dan Konseling di sekolah.

\section{Faktor Pendukung dan Penghambat Bimbingan dan Konseling di SMK Santa Monika Kabupaten Kubu Raya}

Menurut hasil wawancara dengan Guru Bimbingan dan Konseling ST pihak sekolah dan guruguru mendukung pelaksanaan bimbingan dan konseling di SMK Santa Monika. Pihak sekolah juga sudah menyiapkan program bimbingan dan konseling yang akan dilaksanakan dalam proses belajar-mengajar di sekolah.

Program-program yang sudah ada juga dapat memberikan penjelasan dan informasi dari petugas bimbingan dan konseling tentang kurikulum yang sedang berjalan di sekolah.

Guru bimbingan dan konseling ST, dari hasil wawancara juga menyatakan program yang sebagian dilaksanakan dapat membuat siswa lebih terbuka mengungkapkan masalahnya dan betanggung jawab dalam tugas yang diberikan.

Selain itu dari hasil observasi melalui data yang didapat dari responden, keberadaan Bimbingan dan Konseling di SMK Santa Monika sangat penting. Siswa juga sangat terbantu dan termotivasi dalam proses belajar, sehingga pelaksanaan Bimbingan dan Konseling sangat penting untuk dilaksanakan di SMK Santa Monika.

\section{Faktor Penghambat Bimbingan dan Konseling di SMK Santa Monika Kabupaten Kubu Raya}

Menurut hasil wawancara Kepala Sekolah JJ program Bimbingan dan Konseling belum maksimal di SMK Santa Monika. Selain itu, sarana dan prasarana dalam melaksanakan bimbingan dan konseling belum ada. Terbukti tidak adanya ruangan pelayanan pembelajaran umum sebagai ruangan khusus penunjang Bimbingan dan Koseling di SMK Santa Monika.

Menurut hasil wawancara kepada guru Bimbingan dan Konseling ST di SMK Santa Monika ada beberapa faktor penghambat, antara lain:

1. Tenaga guru atau konselor bimbingan dan koseling yang mengajar serta melayani siswa kurang. Sementara ini guru yang menangani atau melayani siswa hanya satu (1) orang. Sementara jumlah keseluruhan siswa SMK Santa Monika 501 orang. Padahal dari program sekolah rasio 1:150 (artinya satu guru melayani 150 siswa). Berarti kekurangan tenaga guru bimbingan dan konseling berjumlah 2 orang. Guru yang mengajar baru tahun ajaran 2014 menjadi guru bimbingan dan konseling dan lebih cocok menjadi konselor. Kurangnya sosialisasi dan komunikasi dalam pelaksanaan bimbingan dan konseling dengan guruguru lain. Perlu waktu dengan guru-guru lain untuk membahas dan membuat program mengenai bimbingan dan konseling.

Upaya yang dilakukan guru Bimbingan dan Konseling dalam Meningkatkan Motivasi Belajar

Implementasi Bimbingan dan Konseling dalam Meningkatkan Motivasi .... 


\section{Siswa Kelas XI di SMK Santa Monika Kabupaten Kubu Raya}

Guru dalam pelaksanaan bimbingam dan konseling berupaya untuk memberikan motivasi terhadap siswa. Motivasi tersebut bisa berupa saransaran yang sangat membantukan siswa dalam proses belajar.

Selain lewat saran-saran, guru bimbingan dan konseling juga menggunakan cara mendata identitas serta observasi dalam bentuk tugas perorangan maupun kelompok untuk memotivasi siswa dalam proses belajar.

Guru bimbingan dan konseling juga memberikan pelayanan kepada siswa mengenai kemampuan diri, sehingga bisa mengetahui tentang bagaimana kemampuan dalam dirinya serta kebiasaan belajar sedikit berubah lebih baik.

\section{Pelaksanaan Bimbingan dan Konseling di SMK Santa Monika Kabupaten Kubu Raya}

Pelaksanaan program Bimbingan dan Konseling masih kurang maksimal dilaksanakan di SMK Santa Monika. Terbukti dari hasil observasi dan wawancara, program bimbingan dan konseling sudah dibuat dengan baik tetapi pelaksanaannya kurang maksimal di SMK Santa Monika.

Program bimbingan dan konseling kurang maksimal dilaksanakan karena kekurangan tenaga guru yang mengajar dalam bidang tersebut. Guru bimbingan dan konseling yang mengajar hanya berjumlah satu (1) orang. Padahal dari hasil wawancara dengan kepada sekolah JJ, pelaksanaan pelayanan bimbingan dan konseling harus diangkat sejumlah guru atau konselor dengan rasio 1:150 (satu guru melayani 150 orang siswa) pada setiap tahun ajaran. Sedangkah jumlah seluruh siswa dari kelas X,XI, dan XII berjumlah 501 orang. Artinya guru yang melaksanakan program bimbingan dan konseling harus berjumlah tiga (3) orang, untuk melayani dan mengajar siswa di SMK Santa Monika.

Menurut hasil wawancara dengan guru bimbingan dan konseling ST, dalam pelaksanaan proses belajarmengajar kurang terbiasa dan tidak begitu mengerti dengan pembuatan perangkat pembelajaran di sekolah. Guru bimbingan dan konseling ST hanya terbiasa memberikan konselor dibandingkan menjadi pengajar di kelas, karena belum pernah sebelumnya menjadi guru. Guru ST juga mempunyai pekerjaan sebagai penerima SPP (Sumbangan Penyelenggaraan Pendidikan) siswa, sehingga kurang bisa terfokus dalam melaksanakan tugas sebagai guru bimbingan dan konseling di SMK Santa Monika.

Florentina
Guru ST hanya melaksanakan program individual, kelompok dan layanan konsultasi di sekolah. Sehingga siswa dari hasil data yang didapat menjadi kurang sering berkonsultasi atau mengadukan permasalahan kepada guru bimbingan dan konseling.

\section{Faktor Pendukung Bimbingan dan Konseling}

Berdasarkan wawancara dengan guru yang bersangkutan ST, pelaksanaan bimbingan dan konseling, didukung oleh pihak sekolah dan guru-guru di SMK Santa Monika. Terbukti dengan pihak sekolah sudah menyiapkan program-progaram yang berhubungan dengan pelaksanaan bimbingan dan konseling. Program-program bimbingan dan konseling yang telah dibuat berguna sekali dalam melayani siswa di SMK Santa Monika.

Program-program yang dibuat, juga dapat memberikan penjelasan dan informasi dari petugas bimbingan dan konseling tentang kurikulum yang sedang berjalan di sekolah. Siswa jadi mengetahui mengenai satuan pendidikan yang dilakukan oleh guru bimbingan dan konseling dengan memperhatikan keseimbangan dan kesinambungan program kurikulum yang sedang berlangsung di sekolah.

Guru Bimbingan dan Konseling ST juga menyatakan program yang telah dilaksanakan memberikan efek keterbukaan terhadap siswa. Siswa lebih terbuka dan bertanggung jawab terhadap tugas yang diberikan di sekolah. Guru Bimbingan dan Konseling harus mengalami mereka. Maksudnya adalah seorang guru bimbingan dan konseling harus bisa mendekati siswa secara perorangan maupun kelompok. Siswa bila sudah merasa dekat dengan gurunya maka akan lebih mudah untuk terbuka dalam masalah yang dihadapi, dan dapat berpengaruh sekali terhadap proses belajar di sekolah.

Responden dalam hal pelaksanaan kegiatan bimbingan dan konseling sangat penting untuk di laksanakan di SMK Santa Monika.

\section{Faktor Penghambat Bimbingan dan Konseling}

Bedasarkan hasil wawancara kepada Kepala Sekolah JJ, program Bimbingan dan Konseling selama ini belum maksimal di SMK Santa Monika. Siswa pada saat waktu pendaftaran untuk masuk sekolah, anak tidak maksimal diarahkan. Peserta didik harus mengetahui bakat dan kemampuan yang dimilikinya melalui test tertulis serta dilakukan oleh guru Bimbingan dan Konseling di SMK Santa Monika. Selain itu, Ketua Program Studi Keahlian atau guru mata pelajaran kompetensi keahlian selaku penguji, agar dapat menentukan kejuruan mana yang sesuai

Implementasi Bimbingan dan Konseling dalam Meningkatkan Motivasi .... 
dengan bakat dan minat siswa. Minat peserta didik dapat diketahui melalui kuisioner yang dilakukan oleh Guru Bimbingan dan Konseling dan Ketua Program Studi Keahlian atau guru mata melajaran kompetensi keahlian selaku penguji. Guru Bimbingan dan Konseling dalam memberikan penyadaran akan potensi diri siswa presentasi responden hanya berjumlah $40 \%$ menyatakan sering.

Berdasarkan hasil wawancara dengan Guru Bimbingan dan Konseling ST ada beberapa faktor penghambat, antara lain: Tenaga guru atau konselor bimbingan dan koseling yang mengajar serta melayani siswa kurang. Guru yang menangani siswa hanya satu (1) orang dan harus melayani 501 orang. Padahal dari program sekolah rasio 1:150 (artinya satu guru melayani 150 siswa). Berarti kekurangan tenaga guru bimbingan dan konseling berjumlah 2 orang di SMK Santa Monika. Padahal siswa yang ingin berkonsultasi dengan keinginan sendiri dalam bimbingan dan konseling presentasinya tinggi. Guru ST juga menyatakan bahwa baru menjadi guru pada tahun ajaran 2014 dan lebih cocok menjadi konselor dibandingkan menjadi seorang tenaga pengajar di kelas. Sehingga belum terbiasa membuat perangkat pembelajaran dan mengajar di kelas. Waktu dalam pelayanan bimbingan dan konseling di luar jam mengajar juga kurang, dikarenakan rangkap kerjaan. Guru harus harus mengajar dan juga penerima SPP (Sumbangan Penyelenggaraan Pendidikan), sehingga sulit untuk membagi waktu ketika siswa ingin berkonsultasi di luar kelas. Siswa sulit berkonsultasi karena belum tersedianya ruangan yang memadai. Kurangnya sosialisasi dan komunikasi dengan guruguru lain dalam pelaksanaan program bimbingan dan konseling. Perlu waktu dengan guru-guru lain, untuk membahas dan membuat program mengenai bimbingan dan konseling yang sesuai dengan kebutuhan atau keadaan siswa di SMK Santa Monika.

Upaya yang dilakukan Guru Bimbingan dan Konseling dalam Meningkatkan Motivasi Belajar Siswa Kelas XI di SMK Santa Monika Kabupaten Kubu Raya

Berdasarkan data yang didapat dari responden, saran-saran yang diberikan oleh guru Bimbangan dan Konseling dapat menambah Motivasi Belajar siswa di SMK Santa Monika.

Selain lewat saran-saran, guru bimbingan dan konseling juga menggunakan cara mendata identitas serta observasi siswa dalam bentuk tugas perorangan maupun kelompok untuk memotivasi siswa dalam proses belajar. Lewat mengidentifikasi data siswa,
Guru Bimbingan dan Konseling lebih mengenal siswa dengan baik. Tugas yang diberikan oleh Guru Bimbingan dan Konseling terhadap siswa, juga dapat menambah rasa tanggung jawab.

Guru bimbingan dan konseling juga memberikan bimbingan kepada siswa mengenai kemampuan diri, sehingga siswa mengetahui tentang bagaimana kemampuan dalam dirinya serta kebiasaan belajar sedikit berubah lebih baik.

\section{Pelaksanaan Bimbingan dan Konseling dalam Meningkatkan Motivasi Belajar Siswa Kelas XI di SMK Santa Monika Kabupaten Kubu Raya}

Pelaksana Pelayanan Bimbingan dan Konseling pada SMK Santa Monika. sudah dilaksanakan di SMK Santa Monika. Terbukti dengan pihak sekolah telah mengadakan Mata Pelajaran Bimbingan dan Konseling serta telah dilaksanakan. Dari hasil wawancara dengan Kepala Sekolah SMK Santa Monika JJ, pihak sekolah telah membuat program-program Bimbingan dan Konseling di sekolah.

Pentinganya Bimbingan dan Konseling di sekolah dalam kurikulum pendidikan pada umumnya dikatakan bahwa tujuan pendidikan akan dicapai melalui tiga bidang kegiatan, yaitu bidang pengajaran, atau kurikuler; bidang administrasi, supervise, dan manajemen; dan bidang bimbingan konseling.

Bidang Bimbingan dan Konseling memegang peran amat penting dalam pencapaian tujuan pendidikan secara keseluruhan dengan alasan sebagai berikut: Setiap individu adalah mahluk yang unik, berbeda dengan yang lain. Setiap peserta didik memiliki bakat, minat, dan tahap perkembangan yang berbeda dengan yang lain. Pendekatan klasikal yang digunakan sekolah selama ini jelas kurang memberikan perhatian pada perbedaan setiap individu. Bidang bimbingan dan Konseling diharapkan mampu menutup kekurangan system klasikal yang digunakan oleh sekolah.

Setiap orang menginginkan agar hidupnya bahagia. Dalam kenyataan banyak anak mengalami persalahan pribadi yang tidak tertangani oleh guru kelas atau guru bidang studi. Jika permasalahan seperti ini tidak ada yang menangani akan berdampak pada gangguan belajar anak dan juga ketidabahagiaan dalam hidup anak. Pada zaman ini banyak orang tua sibuk bekerja, bahkan kedua orang tua semuanya bekerja. Mereka kurang memiliki waktu untuk pendampingan dan pendidikan anak. Tambahan lagi masih banyak orang tua berpandangan bahwa urusan pendidikan anak dipercayakan sepenuhnya kepada sekolah, padahal waktu anak di sekolah sangatlah pendek jika Implementasi Bimbingan dan Konseling dalam Meningkatkan Motivasi .... 
dibandingkan dengan waktu anak di dalam keluarga. Dalam hal inilah kegiatan Bimbingan dan Konseling diharapkan dapat menjadi jalan keluarnya. (Martin Handoko dan Theo Riyanto, 2010:12-13)

\section{Faktor Pendukung Bimbingan dan Konseling}

Pihak sekolah dan guru-guru yang lain mendukung pelaksanaan bimbingan dan konseling di SMK Santa Monika. Pihak sekolah juga sudah menyiapkan program bimbingan dan konseling yang akan dilaksanakan dalam proses belajar-mengajar di sekolah.

Program-program yang sudah ada juga dapat memberikan penjelasan dan informasi dari petugas bimbingan dan konseling tentang kurikulum yang sedang berjalan di sekolah.

Guru bimbingan dan konseling ST, dari hasil wawancara juga menyatakan program yang sebagian dilaksanakan dapat membuat siswa lebih terbuka mengungkapkan masalahnya dan betanggung jawab dalam tugas yang diberikan.

Selain itu dari hasil observasi melalui data yang didapat dari responden, keberadaan Bimbingan dan Konseling di SMK Santa Monika sangat penting. Siswa juga sangat terbantu dan termotivasi dalam proses belajar, sehingga pelaksanaan Bimbingan dan Konseling sangat penting untuk dilaksanakan di SMK Santa Monika.

Dalam rumusan Bimbingan dan Konseling terdapat dua tujuan yaitu tujuan umum dan tujuan khusus. Tujuan umum Bimbingan dan Konseling adalah untuk membantu individu memperkembangkan diri secara optimal sesuai dengan tahap perkembangan dan predisposisi.

Sedangkan tujuan khusus Bimbingan dan Konseling adalah merupakan penjabaran dari tujuan umum tersebut yang dikaitkan secara langsung dengan permasalahannya itu. Masalah-masalah individu yang bermacam ragam jenis, intensitas dan sangkut-pautnya serta masing-masing bersifat unik. Oleh karena itu tujuan khusus Bimbingan dan Konseling untuk masing-masing individu berbeda dari (dan tidak boleh disamakan dengan) tujuan Bimbingan dan Konseling untuk individu lainnya. (Priyatno dan Ermananti, 1999:114).

\section{Faktor Penghambat Bimbingan dan Konseling}

Menurut hasil wawancara Kepala Sekolah JJ program Bimbingan dan Konseling belum maksimal di SMK Santa Monika. Selain itu, sarana dan prasarana dalam melaksanakan bimbingan dan konseling belum ada. Terbukti tidak adanya ruangan pelayanan pembelajaran umum sebagai ruangan khusus penunjang Bimbingan dan Koseling di SMK Santa Monika.

Menurut hasil wawancara kepada guru Bimbingan dan Konseling ST di SMK Santa Monika ada beberapa faktor penghambat, ialah tenaga guru atau konselor bimbingan dan koseling yang mengajar serta melayani siswa kurang. Sementara ini guru yang menangani atau melayani siswa hanya satu (1) orang. Guru yang mengajar baru tahun ajaran 2014 menjadi guru bimbingan dan konseling dan lebih cocok menjadi konselor.

Sosialisasi dan komunikasi kurang dengan guruguru lain. Perlu waktu dengan guru-guru lain untuk membahas dan membuat program mengenai bimbingan dan konseling.

Menurut Hibana S. Rahman (2003:13 dan 18), bimbingan adalah proses bantuan yang diberikan kepada seseorang agar ia mampu memahami diri, menyesuaikan diri dan mengembangkan diri sehingga mencapai kehidupan yang sukses dan bahagia. Sedangkan konseling adalah proses pemberian bantuan yang dilakukan melalui wawancara oleh seorang konselor terhadap individu.

Upaya yang dilakukan guru Bimbingan dan Konseling dalam Meningkatkan Motivasi Belajar Siswa Kelas XI di SMK Santa Monika Kabupaten Kubu Raya

Guru dalam pelaksanaan bimbingam dan konseling berupaya untuk memberikan motivasi terhadap siswa. Motivasi tersebut bisa berupa saransaran yang sangat membantukan siswa dalam proses belajar.

Selain lewat saran-saran, guru bimbingan dan konseling juga menggunakan cara mendata identitas serta observasi dalam bentuk tugas perorangan maupun kelompok untuk memotivasi siswa dalam proses belajar.

Guru bimbingan dan konseling juga memberikan pelayanan kepada siswa mengenai kemampuan diri, sehingga bisa mengetahui tentang bagaimana kemampuan dalam dirinya serta kebiasaan belajar sedikit berubah lebih baik.

\section{SIMPULAN}

Berdasarkan hasil penelitian dan pembahasan Bimbingan dan Konseling dalam Meningkatkan Motivasi Belajar Siswa Kelas XI di SMK Santa Monika Kabupaten Kubu Raya, dapat disimpulkan bahwa Pelaksanaan Bimbingang dan Konseling dalam Meningkatkan Motivasi Siswa Kelas XI di SMK Santa

Implementasi Bimbingan dan Konseling dalam Meningkatkan Motivasi .... 
Monika Kabupaten Kubu Raya berorientasi pada : Layanan Orientasi, Layanan Informasi, Layanan Penempatan Penyaluran, Layanan Penguasaan Konten, Layanan Konseling Perseorangan, Layanan Bimbingan Kelompok, Layanan Konseling Kelompok, Layanan Konsultasi, Layanan Mediasi, Layanan Advokasi, Faktor pendukung dan faktor penghambat bimbingan dan konseling dalam meningkatkan motivasi siswa kelas XI di SMK Santa Monika Kabupaten Kubu Raya :Faktor pendukung dari pelaksanaan bimbingan dan konseling pihak sekolah dan guru-guru mendukung dengan membuat program-program layanan bimbingan dan konseling. Faktor penghambat ialah kekurangan tenaga guru atau konselor, keterbatasan waktu, dan guru yang mengajar tidak terbiasa dalam mengajar di kelas. Upaya yang dilakukan guru bimbingan dan konseling dalam meningkatkan motivasi siswa kelas XI di SMK Santa Monika Kabupaten Kubu Raya ialah mendata anak dengan pengisian identitas siswa, mengalami atau mendekati siswa, membuat program individu atau kelompok dan memberikan saran-saran terhadap siswa kelas XI di SMK Santa Monika Kabupaten Kubu Raya.

\section{DAFTAR PUSTAKA}

Anas Sujiono. (1995) Pengantar Statistik Pendidikan. Jakarta: PT. Raja Grafindo Persada.

Departemen Pendidikan Nasional. (2007) Kamus Besar Bahasa Indonesia. Jakarta: Balai Pustaka.

Yusuf Syamsu. (2000) Psikologi Perkembangan Anak dan Remaja. Bandung: PT Remaja Rosdakarya.

Handoko Martin dan Riyanto Theo. (2010) Bimbingan dan Konseling Sekolah. Yogyakarta: Kanisius.

Hibana S. Rahman. (2003) Bimbingan dan Konseling Pola 17 Cet.J. Yogyakarta: UCY Press.

Dahlan Djamad. (2002) Psikologi Perkembangan Anak dan Remaja. Bandung: PT Remaja Rosdakarya.

Marti Handoko. (1995) Motivasi Penngerak Tingkah Laku. Yogyakarta: Kanisius

Muhiibin Syah. (1997) Psikologi Pendidikan dengan Pendekatan Baru, Bandung: PT Remaja Rosdakarya

M. Hamdani Bakran Ad-Dzaky. (2002) Konseling dan Psikoterapi Islam. Yogyakarta: Fajar Pustaka Baru.

Nawawi, Hadari. (1993) Metode Penelitian Bidang Sosial. Yogyakarta:Gajah Mada Press.

Ngalim Purwanto. (1997) Psikologi Pendidikan, Bandung: PT Remaja Rosdakarya

Priyatno dan Ermananti. (1999) Dasar-Dasar Bimbingan Konseling Cet.J. Jakarta: Rineka Cipta.

Saiful Bahri Djamaroh. (2002) Psikologi Belajar. Jakarta: Rineke Cipta
Sardiman AM. (1997) Interaksi dan Motivasi Belajar Mengajar. Jakarta: Rajawali Press

Satori, Djaman dan Aan Komariah. (2010) Metode Penelitian Kualitatif. Bandung: Alfabeta.

Suharsimi Arikunto. (2002) Prosedur Penelitian Suatu Pendekatan Praktis. Jakarta: Rineka Cipta.

Sutrisno Hadi. (2000) Metodologi Reseach 2. Yogyakarta: Andi Offset.

Sutari Imam Barnadib. (1994) Dasar-Dasar Perbandingan Pendidikan Sistematis. Yogyakarta: Andi Offset.

Tim Penyusun Kamus Pusat Pembinaan dan Pengembangan Bahasa. (1997) Kamus Besar Bahasa Indonesia. Jakarta: DEPARTEMEN Pendiddikan dan Kebudayaan Republik Indonesia

Sukardi Ketut Dewa. (1983) Bimbingan dan Penyuluhan Belajar di Sekolah. Surabaya, Usaha Nasional.

Sumadi Suryabrata. (2001) Psikologi Pendidikan, Jakarta: Gravindo Persada

Sumadi Suryabrata. (2007) Psikologi Pendidikan. Jakarta, PT RajaGrafundo.

Wasti Soemanti. (2002) Psikologi Pendidikan Landasan Kerja Pimpinan pendidikan. Jakarta: Rineke cipta

Winarno Surahman. (1990) Penelitian-Penelitian Ilmiah Dasar Metode Teknik. Bandung: Tarsito.

Winkel. (1987) Psiokologi Pengajaran. Jakarta: PT Gramedia.

Wina Senjaya. (2008) Strategi Pembelajaran: Berorientasi Standar Proses Pendidikan. Jakarta:Kencana Prenada Media Group.

WS Winkel. (1996) Psikologi Pengajaran. Jakarta: Gramedia Widiasarana Indonesia 